\title{
Gerdocypris, a new genus of Paracyprididae (Ostracoda) from the North Atlantic, Mediterranean and East Africa
}

\author{
KENNETH G. MCKENZIE \\ Riverina CAE, Wagga Wagga, 2650, Australia
}

\begin{abstract}
The genus Gerdocypris (type species Gerdocypris muelleri sp. nov.) is described as new based on a mature male from the Bay of Naples. Gerdocypris ranges from the North Atlantic and Mediterranean to East Africa. Its differences from Aglaiocypris and Aglaiella are discussed and tabulated.
\end{abstract}

\section{INTRODUCTION}

The description by Hartmann (1964) of a new genus, Ghardaglaia, from the Red Sea and the comparison of this genus with Aglaiocypris Sylvester-Bradley, 1947 originally described from Messina, Sicily (Brady, 1868) and Aglaiella Daday, 1910 described from the Mareotis, Alexandria, Egypt, refocussed attention upon a difficult group of related genera in the ostracod family Paracyprididae. Re-examination of types and new material led McKenzie (1982) to a brief review of these and some related taxa, including Tasmanocypris McKenzie, 1979. As a result, several taxa previously assigned to Aglaiocypris are now known to be distinct from that genus (and the other genera listed above) necessitating the description of a new paracypridid genus.

\section{SYSTEMATIC DESCRIPTIONS \\ Suborder Podocopina Sars, 1866 \\ Superfamily Cypridacea Baird, 1845 \\ Family Paracyprididae Sars, 1923 \\ Genus Gerdocypris McKenzie gen. nov.}

(Pl. 1, figs. 1-15)

Type species. Gerdocypris muelleri sp. nov.

Derivation of name. For Prof. Gerd Hartmann, the University of Hamburg, in recognition of his many contributions to ostracod taxonomy.

Diagnosis. A genus of the family Paracyprididae characterised by a weakly calcified, regularly elongate beanshaped carapace, smooth surfaced and whitish. Inner lamellae broad anteriorly and ventrally, narrow posteriorly; marginal pore canals short and straight, except ventrally where a few are longer; normal pore canals simple, rimmed; muscle scars of general cypridacean type; male shell bears the imprints of 4 strands of seminal vesicles posteriorly. Antennule 5-segmented; antenna with strongly reduced 'natatory' setae: maxillule epipod with 3 downwards directed setae and about 10 Strahlen, 3rd lobe with 2 smooth Zahnborsten; P1 epipod with 6 Strahlen; P2 terminal claw long, slender and regularly curved; P3 5-segmented, the long reflexed bristle jointed at about $2 / 3$ its length from the proximal end; furcal lamella short and broad, with 2 strong stubby claws, an anterior bristle and 2 longish posterior bristles; rake like organ with 14 small teeth. Hemipenis with coils opening ventrally, peniferum digitate; Zenkers Organ with 5 whorls; endopods of the male P1 symmetrical,i.e. not dissimilar on right and left of the body.

Remarks. McKenzie (1982, pp. 416-417) points out that Aglaia complanata (Brady \& Robertson, 1870) which was figured in the American Treatise (Moore, 1961) as representing Aglaiocypris is not an example of this genus, having a different radial pore canal pattern and a different soft anatomy. The former character has been confirmed from examination of specimens of $A$. complanata in the Norman Collection at the British Museum (Natural History). Unfortunately, no dissection slides for the taxon are available in the BM (NH) collections.

The finding recently of a mature male of the species identified by G.W. Müller (1894) as A. complanata enables a more detailed comparison with the male described by Brady (1868) among the syntypes of Aglaia pulchella Brady, 1868 which is the type species of Aglaiocypris. The re-illustration of the type of Aglaiella (McKenzie, 1982, Pls. 5, 6) also enables a comparison with that genus (Table 1).

In addition to the data presented in Table 1, Aglaiella differs from Gerdocypris in that the reduced 'natatory' setae of the antennae are somewhat longer in Aglaiella and more numerous ( 5 in Aglaiella versus 3 in Gerdocypris).

\section{Gerdocypris muelleri sp. nov.}

Derivation of name. After G.W. Müller, who described and illustrated this taxon as A. complanata in his Bay of Naples monograph (Müller, 1894).

Description. Carapace of medium size (length $0.73 \mathrm{~mm}$ ), 


\begin{tabular}{|c|c|c|c|}
\hline & Gerdocypris & Aglaiella & Aglaiocypris \\
\hline Number of antennular segments & 5 & 6 & 7 \\
\hline Number and type of Zahnborsten & 2, smooth & 2, smooth & 3, smooth \\
\hline Ventromarginal furcal bristles & long & short & short \\
\hline Radial pore canals & short, straight & $\begin{array}{l}\text { moderately long, } \\
\text { some branched }\end{array}$ & long, branched \\
\hline Imprints of seminal vesicles on shell & 4 & not known & 7 \\
\hline Shell patch pattern & absent & absent & present \\
\hline Nature of shell & weakly calcified & well calcified & strongly calcified \\
\hline
\end{tabular}

Table 1. Some differences between the shells and soft anatomies of Gerdocypris, Aglaiella and Aglaiocypris.

regularly elongate bean-shaped and weakly calcified; greatest height medial and less than half the length; dorsum regularly arched; venter inflexed near-medially; anterior and posterior margins subequally rounded, the posterior slightly narrower. In dorsal view, elongate subelliptical; greatest width medial and less than half the length; extremities subacuminate. Surface of the valves smooth; colour whitish. Inner lamellae broad anteriorly and ventrally, narrow posteriorly; line of concrescence submarginal; consequently the radial pore canals are very short and straight (not particularly numerous) except ventrally where a few are longer; normal pore canals scattered, simple, rimmed; muscle scars comprising a cypridacean rosette of 3 anterior and 2 posterior adductors (the uppermost adductor divided), a fulcral scar, plus 2 small mandibular scars (Pl. 1, fig. 1).

Antennule 5-segmented; length ratios of the segments about $5: 1: 3: 1: 0.5 ; 1$ st segment with a proximodorsal and 2 long ventrodistal bristles; 2 nd segment with a dorsodistal bristle; 3 rd segment carrying 1 mediodorsal and 1 mediodistal bristle; 4th segment with 4 bristles,
3 of them long and 1 very long; 5th segment with 4 terminal bristles, 3 long (including 1 very long) and 1 short and slender (Pl. 1, fig. 2).

Antenna 6-segmented; comprising coxale, basale, exopod and endopod. Coxale with 2 unequal relatively short ventrodistal bristles; basale with a long ventrodistal bristle. Exopod reduced to a small baseplate bearing 3 unequal bristles, 1 about half the length of the 1 st endopod segment, the remaining 2 very small. Endopod 4-segmented; length ratios of the segments $11: 4: 4: 2$; 1 st segment with a well developed near proximal Y-aesthetasc, a ventrodistal bristle and a small subventrodistal clump of 3 short bristles (which are the strongly reduced relicts of natatory bristles); 2nd segment with a medioventral bristle and 2 distal bristles, plus a ventrodistal claw; 3 rd segment with 2 distal claws and a distal bristle, the 2 claws dorsal ( 1 of them very strong), the bristle ventral and short; 4th segment with a strong distal claw and 2 slender distal bristles (PI. 1, fig. 3).

\section{Explanation of Plate 1}

All figures are $\times 425$ unless otherwise specified.

Gerdocypris muelleri McKenzie gen. et sp. nov., mature male, Secca di Forio, Bay of Naples; BM(NH) no. 1982.176, holotype.

Fig. 1, RV, int. lat. ( $\times 140$ ); fig. 2, antennule; fig. 3, antenna; fig. 4, mandible (chaetotaxy omitted); fig. 5, maxillule, showing the 3 downwards-directed bristles of the epipod, the palp and lobes with the 2 smooth Zahnborsten of the 3rd lobe; fig. 6, head region; fig. 7, maxilla (P1), epipod and exopod; fig. 8, rake-like organ; fig. 9, chitin support; figs. 10, 11, P3 (Cleaning Limb); fig. 12, hemipenis; fig. 13, furca; figs 14, 15, P2 (Walking Leg). 


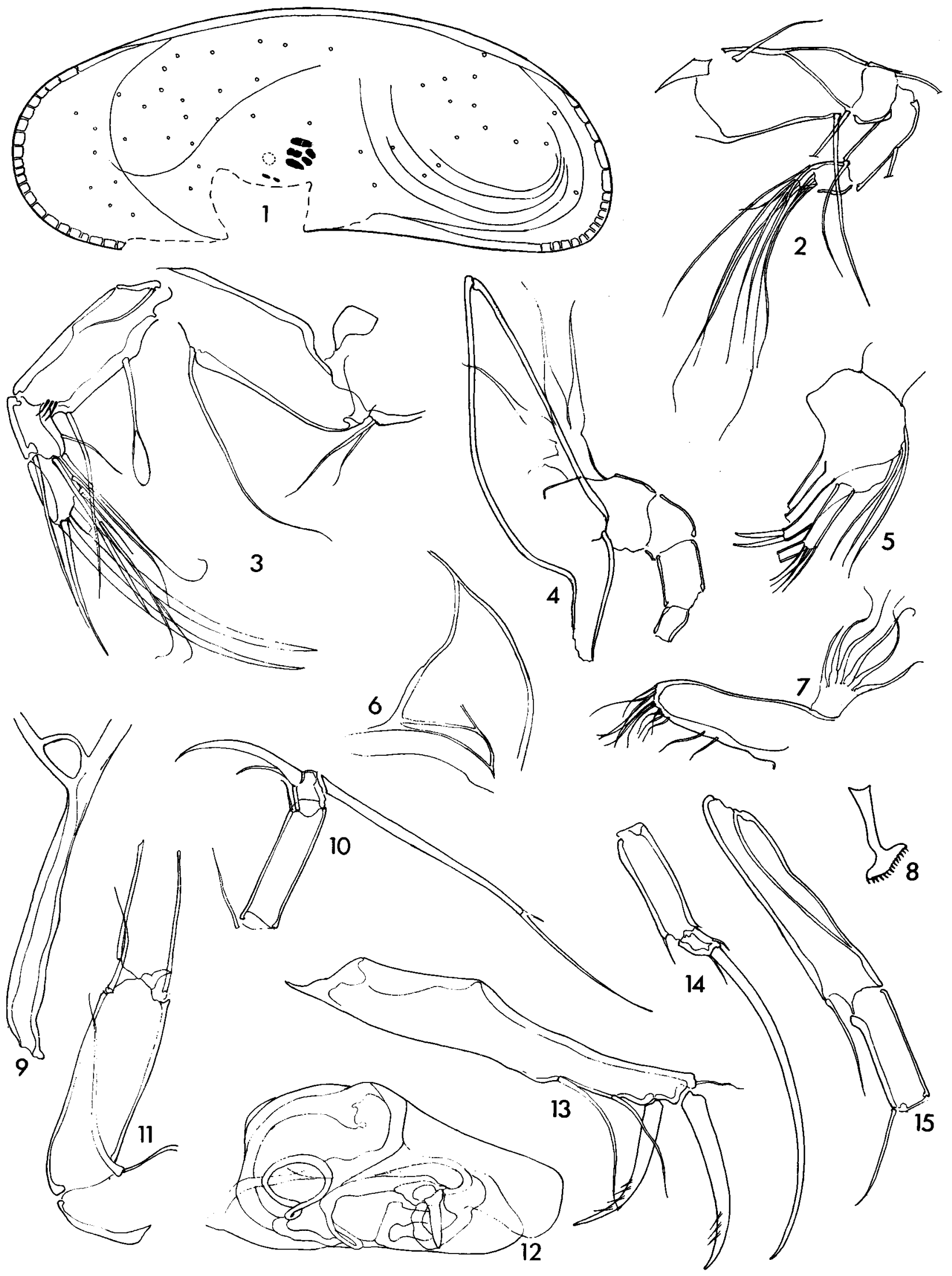


Mandible comprising coxale, basale, epipod and endopod. Coxale with at least 4 strong teeth, the anteriormost incisor-like, the others molar-like and decreasing in size from front to rear, plus a medial anterior bristle and 2 small sideways-directed posteroventral bristles. Basale with 3 ventral bristles, one of them a slender $\alpha$ bristle. Epipod with at least 4 Strahlen. Endopod 3-segmented; length ratios of the segments $3: 4: 2 ; 1$ st segment with a dorsodistal bristle and a clump of at least 3 (and probably 4 ) ventrodistal bristles, but a $\beta$ bristle could not be distinguished; 2 nd segment with 5 dorsodistal bristles, a mediodistal bristle and 2 ventrodistal bristles (the mediodistal bristle undifferentiated); 3 rd segment with 2 terminal claws (one larger than the other) and at least 1 slender terminal bristle (Pl. 1, fig. 4).

Maxillule comprising epipod, endopod and lobes. Epipod with 10 Strahlen and 3 downwards-directed bristles. Palp and lobes elongate; palp 2-segmented; length ratio of the segments $5: 2 ; 3$ rd lobe with 2 smooth Zahnborsten (Pl. 1, fig. 5).

Maxilla (P1) comprising protopod, epipod, exopod and endopod. Protopod possibly bare. Epipod with 6 Strahlen. Exopod with a terminal cluster of about a dozen slender bristles plus 2 more proximal ventral bristles. Endopod obscured on the dissection slide but Müller (1894, Pl. 12, Fig. 42) illustrates a small 2segmented palp with a simple sigmoidal terminal clasping part ending in a small spine-presumably the right and left endopods are not dimorphic in the male since Müller does not record dimorphism. Female endopod (Müller, 1894, Pl. 12, fig. 43) a simple lobe with 3 terminal bristles ( $\mathrm{Pl} .1$, fig. 7).

P2 (Walking Leg) with a 4-segmented endopod; length ratios of the segments $12: 6: 6: 1.5 ; 1$ st and 2 nd segments each bearing a ventrodistal bristle of similar length; 3rd segment with a short ventrodistal bristle; 4th segment with single short ventro- and dorsodistal bristles plus a long, slender and regularly curved terminal claw (Pl. 1, figs. 14, 15).

P3 (Cleaning Limb) reflexed, 5-segmented; length ratios of the last 4 segments about 10:6:6:1.7; 1 st segment with at least 1 long bristle (ventrodistally); 2 nd segment and 3rd segment each bearing a dorsodistal bristle of similar length; 4 th segment with a short dorsodistal bristle; 5 th segment with a short terminal bristle and 2 opposed larger bristles, the smaller of these clawlike (about twice the length of the short bristle) and the larger about 3 times longer than the claw-like bristle and divided at about ${ }^{2} / 3$ its length from the proximal end (Pl. 1, figs. 10, 11).

Furca bilamellar, short and broad; each lamella with 2 strong, stubby terminal claws which are spinose distally, plus a slender anterodistal bristle and 2 nearly equal slender bristles (almost as long as the claws) on the margin behind the posterior claw but well separated from it and from each other (Pl. 1, fig. 13).

Chitin Support thick, rather pointed at the end where it connects with the furca and forked proximally with a large eyelet in the fork ( $\mathrm{Pl} .1$, fig. 9).

Head region simple, arcuate, coming to a point at the tip of the labrum (Pl. 1, fig. 6).

Rake-like organ with about 14 small teeth (PI. 1, fig. 8).

Hemipenis subquadrate; anterior lobes rather broadly rounded; seminal tube complexly coiled, the coils opening downwards; copulatory process broadly pointed, digitate (Pl. 1, fig. 12).

Zenker's Organ with 5 inner whorls.

Holotype. A mature male BM(NH) no. 1982.176 comprising 2 separated valves (somewhat damaged during dissection) on a microslide, plus a dissection slide.

Material. Single mature male (the holotype), plus several juveniles.

Locality. Secca di Forio, Bay of Naples; depth $50 \mathrm{~m}$.

$\begin{array}{cll}\text { Dimensions (mm) } & \text { Length } & \text { Height } \\ \text { Holotype } & 0.73 & 0.295\end{array}$

Remarks. The new species is very similar to Aglaia complanata as represented in the Norman Collection at the $\mathrm{BM}(\mathrm{NH})$, especially the specimen from Birterbuy Bay, Ireland (no. 1911.11.8 M.2998). Unfortunately, this specimen is broken and appears to be an A-1 juvenile without soft parts. The other specimen of $A$. complanata in the collections (no. 1911.11.8 M.2997), a left valve, is mature and higher with respect to its length also more robustly calcified than Gerdocypris muelleri. It, too, lacks soft parts.

Due to the unsatisfactory nature of these specimens, it seems preferable at this stage to describe $G$. muelleri as a new species, while recognising that better and topotypic material of $A$. complanata may lead subsequently to the synonymising of muelleri with complanata.

Another species which clearly belongs in Gerdocypris is Aglaiocypris eulitoralis Hartmann, 1974. The soft parts of $A$. eulitoralis are very close to those of $G$. muelleri, except that on the furca the posterior of the 2 bristles on the ventral margin of the lamella is about twice as long as the anterior ventromarginal bristle, whereas in $G$. muelleri this bristle is only slightly longer than the anterior ventromarginal bristle. In size and shape A. eulitoralis is smaller and somewhat higher with respect to its length than $G$. muelleri (Hartmann, 1974 , Pl. 144, figs. 995-1005).

Gerdocypris as presently understood, therefore, includes the species:

Gerdocypris muelleri sp. nov. (the type species);

Gerdocypris complanata (Brady and Robertson, 1870); and

Gerdocypris eulitoralis (Hartmann, 1974).

The genus is distributed through the North Atlantic (complanata), in the Mediterranean (muelleri) and on 
the coast of East Africa (eulitoralis); at depths ranging from the littoral to about $50 \mathrm{~m}$.

\section{ACKNOWLEDGEMENTS}

Dr. G. Bonaduce collected the mature male and other specimens on which this description is based and provided facilities at Stazione Zoologica, Naples, during February-March 1982. Drs. R.H. Bate and G. Boxshall provided facilities, and access to the library and collections, during June 1982 at the British Museum (Natural History), London. Also at the BM(NH) Dr. L.M. Sheppard gave advice on the paper's format and Miss A. Gurney measured the holotype. The type material of Aglaiocyp, ris pulchella (Brady, 1868) was loaned by Mr. A. Tynan, Curator of the Hancock Museum, Newcastleupon-Tyne; the type of Aglaiella stagnalis Daday, 1910 was loaned by Dr. G. Pretzmann, of the Natural History Museum, Vienna.

\section{REF ERENCES}

Brady, G.S. 1868. Fonds de la Mer, Vol. I, 316 pp. (Folin \& Perrier, Paris)

Hartmann, G. 1964. Zur Kenntnis der Ostracoden des Roten Meeres. Kieler Meeresforsch., 20, 35-127.

Hartmann, G. 1974. Zur Kenntnis des Eulitorals der afrikanischen Westküste zwischen Angola und Kap der Guten Hoffnung und der afrikanischen Ostküste von Südafrika und Mocambique unter besonderer Berücksichtigung der Polychaeten und Ostracoden. III, Die ostracoden des Untersuchungs-gebiets. Mitt. Hamb. Zool. Mus. Inst., 69, $229-520$.

McKenzie, K.G. 1979. Tasmanocypris, a new marine ostracode genus and a review of the family Paracyprididae (Crustacea, Ostracoda). Pap Proc. R. Soc. Tasm., Hobart, 113, 29-37.

McKenzie, K.G. 1982. Homoeomorphy: persistent joker in the taxonomic pack, with the description of Bradleycypris gen. nov. In Bate, R.H., Robinson, E. \& Sheppard, L.M. (Eds.), Fossil and Recent Ostracods, 407-438 (Ellis Horwood Ltd., Chichester for British Micropalaeontological Society.

Moore, R.C. 1961 (Ed.). Treatise on Invertebrate Paleontology. Pt. Q. Arthropoda, 3, xxiii +442 pp., 334 figs. Univ. Kansas Press.

Müller, G.W. 1894. Die Ostracoden des Golfes von Neapel und der angrenzenden Meeres-Abschitte. Fauna Flora Golfes Neapel, Monog., 21, 1-404. 